\title{
6. The Atmospheric Screen: Turner, Hazlitt, Ruskin
}

\author{
Antonio Somaini
}

\begin{abstract}
Antonio Somaini questions the veils, mists, and fogs that appear in the late works of J.M.W Turner, suggesting that here the canvas gains the status of an 'atmospheric screen'. Drawing on the etymology of the term 'medium', Somaini probes the re-emergence in the nineteenth century of an environmental media concept in relation to the rediscovery of the environmental nature of the screen. Their parallel genealogies, he suggests, intersect in Romantic landscape painting as well as in German Naturphilosophie and Romantic Literature, each of which might be situated within a line of descent running from Aristotle's notions of metaxy to mediaeval theories of media diaphana. The controversies over Turner's canvases, exemplified by the debate between Ruskin and Hazlitt, are a potent reminder of the unsettled status of the atmosphere at a moment when the optical conception of the screen was not yet dominant.
\end{abstract}

Keywords: Romanticism, Painting, Medium, Atmosphere, Landscape

In his 'Notes on a Genealogy of the Excessive Screen' - the text that introduced Yale's Mellon Sawyer Seminar, Genealogies of the Excessive Screen, from which the essays in this volume originate-Francesco Casetti presents the history of screens and of the very term 'screen' as the intertwining of two different traditions. On the one hand there is a tradition, beginning in the early nineteenth century, that considers the screen to be first and foremost an optical device: a material surface onto which an image is projected or from which an image emanates. On the other hand, there is an older tradition within which the term 'screen' suggests a number of spatial entities producing some kind of division in the physical environment. Casetti writes:

Buckley, C., R. Campe, F. Casetti (eds.), Screen Genealogies. From Optical Device to Environmental Medium. Amsterdam: Amsterdam University Press, 2019 DOI 10.5117/978946372900o_CHo6 
Screens are not only optical devices. Since the $15^{\text {th }}$ century the English word screen, as well as the French écran, the Italian schermo, the German Schirm, have denoted objects that perform functions other than supporting a projected representation. A screen was a contrivance for warding off the heat of a fire or a draft of air, a partition of wood or stone dividing a room or a building into parts, a wall thrown out in front of a building to mask the façade, a tactical deployment of soldiers to conceal the movement of an army, an apparatus used in the sifting of grain and coal. It was a filter, a divide, a shelter, a camouflage. These functions underscored not so much the optical qualities of a screen but rather its environmental character-its nature as a prop to be used within and towards a space. ${ }^{1}$

If analyzed from an archaeological perspective-one that studies the present from the vantage point of the past and the past from the vantage point of the present, recognizing the fact that our historical reconstructions are often the result of some kind of 'retroactive causality' — then the transformations that screens are currently undergoing may be interpreted in relation to the intertwining of the two different traditions highlighted by Casetti. ${ }^{2}$ The fact that the ubiquitous screens of our computers, tablets, and smartphones are at the same time both optical displays and highly networked digital devices (which perform crucial spatial and environmental operations in terms of mapping, orientation, geolocalization, and even concealment) invites us to rediscover the older spatial and environmental meanings of the term 'screen'. As Casetti writes: 'Screens have become again filters, shelters, divides, and camouflage. They remain surfaces that display images and data, and yet their opticality is deeply rooted in their spatial and environmental conditions.'3

A similar dynamic, I would like to argue, may be detected if we turn from the history of the term 'screen' to that of another term that is firmly connected to it: the term 'medium'. An archaeological approach to the history of the medium as a concept-a medium archaeology that tries to understand what media are becoming today by exploring the multiple

1 Casetti, 2017. In a footnote of his text published in this volume (Casetti's footnote n.23), Casetti suggests that the first occurrence of the optical meaning of the English term 'screen' can probably be found in two notices referring to the patent granted on 26 January 1802 to Paul De Philipsthal, which is probably the English name used by Paul Philidor, a magician and pioneer of the Phantasmagoria shows.

2 On media archaeology and the idea of 'retroactive causality', see Elsaesser, pp. 71-10o, in particular pp. 80-86.

3 Ibid. 
meanings that have been associated with the term 'medium' in the pastcomes to conclusions similar to Casetti's. If the spatial and environmental functions performed by contemporary, digitally networked screens invite us to rediscover a past in which screens were considered to be 'filters, shelters, divides, and camouflage', then the current interest in the environmental and ecological dimensions of media-in the ever-deeper intertwinings of nature and communication technologies and in how contemporary media serve as infrastructural environments that reorganize the human sensorium-invites us to re-explore the longue durée of a tradition in which the term 'medium' did not indicate, yet, a series of technical means of (mass) communication but rather the environment, the milieu, or the Umwelt in which sensory experience takes place. This tradition was recently highlighted by John Durham Peters in The Marvellous Clouds: Towards a Philosophy of Elemental Media. As he writes, 'the concept of media [...] was connected to nature long before it was connected to technology [...]. Medium has always meant an element, an environment, a vehicle in the middle of things'. ${ }^{4}$ If we want to understand the spatial, environmental dimension of contemporary media, Peters writes, we need to revisit 'the older, environmental meaning of medium' and the 'elemental legacy of the media concept'.5

If we accept both Casetti and Peters's suggestions- that both screens and media are currently undergoing a series of transformations that can be better understood if we rediscover their older spatial and environmental dimensions - we may ask ourselves when and how the history of the 'screen' and that of the 'medium' intersected one another, and what was the result of such intersections. Several historical periods and several constellations of discourses and practices could be studied in this perspective. For example, in the 1920s and 1930s, László Moholy-Nagy used the term 'medium' to refer to the environmentally diffused element of light, imagining a future in which an art conceived as a form of 'light configuration' (Lichtgestaltung) could completely transform the cinematic dispositif by projecting 'light plays' (Lichtspiele) onto clouds and other 'gaseous formations' rather than onto the traditional flat, bidimensional screen. ${ }^{6} \mathrm{Or}$, in the 1960 os and 1970 ,

4 Peters, p. 46.

5 Ibid., pp. 3-4.

6 See Moholy-Nagy, 1923; Moholy-Nagy, 1936, p. 40. See also the way in which Moholy-Nagy, in his von material zu architektur (German edition 1929, published in 1938 in English in a revised version as The New Vision), presents his camera-less Fotogrammen as a technique in which 'the surface becomes a part of the atmosphere [atmosfäre], of the atmospheric background, in that it sucks up the light phenomena produced outside itself'. Moholy-Nagy, 2001, p. 9o; Moholy-Nagy, 1975 , p. 86. 
Marshall McLuhan insisted that media be understood as 'environments', while a number of artistic practices within the field of so-called 'expanded cinema' explored the screen in its spatial, environmental, and atmospheric dimension. ${ }^{7}$ Among the many examples one might refer to is Joan Brigham and Stan VanDerBeek's Steam Screens (1979), a performance in which film images were projected onto clouds of steam in the sculpture garden of the Whitney Museum of American Art in New York.

Rather than focusing on two foundational periods in the history of media theory, such as the 1920s-1930s and the 1960s-1970s, this essay will take a step back in time and consider the case of an earlier intersection between screen and medium. This earlier intersection can be found during the first decades of the nineteenth century within the context of British Romanticism, when critics and essayists such as William Hazlitt and John Ruskin reflected on the representation of atmospheric elements in the work of Joseph Mallord William Turner, while Turner himself revolutionized the tradition of landscape painting. It is in this period that we find some of the most interesting occurrences of the idea of the medium as a sensible, atmospheric environment, one that is characterized by the presence of natural screening and veiling entities such as clouds, fog, and mist. And it is in this same period, in the late paintings of Turner, that the canvas - rather than being treated as a flat, opaque surface or as an open, transparent window — becomes something different: an atmospheric screen capable of capturing and visualizing the turbulent fusion of the atmospheric elements and of leading the spectator right in the midst of it, abolishing any clear-cut separation between seer and seen and becoming itself, one might say, a part of the atmosphere.

\section{'The medium through which they are seen'}

In order to investigate the intersection between the ideas of screen and medium taking place during the early nineteenth century in England, we may take as a starting point a passage from an essay by William Hazlitt entitled 'On Imitation': a text published in 1817 in the second volume of The Round Table: A Collection of Essays on Literature, Men, and Manners. ${ }^{8}$ In it, Hazlitt tries to respond to the old question of why 'objects in themselves disagreeable or indifferent, often please in the imitation.' ' 'One chief reason 
[...] why imitation pleases', writes Hazlitt, 'is because, by exciting curiosity, and inviting a comparison between the object and the representation, it opens a new field of inquiry, and leads the attention to a variety of details and distinctions not perceived before. ${ }^{10}$ Drawing a parallel between scientific and artistic visual representations, Hazlitt sees in imitation a form of knowledge based on the capacity of capturing a series of 'details' and 'distinctions in nature' that are not accessible to any kind of unmediated perception. ${ }^{11}$ This is true also of objects that are at first displeasing: 'Imitation renders an object displeasing in itself a source of pleasure, not by repetition of the same idea, but by suggesting new ideas, by detecting new properties, and endless shades of difference."12

In the second half of his essay, Hazlitt highlights the excesses to which this idea of imitation may lead. Too much attention to the reproduction of details, distinctions, and 'shades of difference' may produce a form of 'picturesque' in which the pictorial representation becomes an end in itself. ${ }^{13}$ Instead of promoting 'a more intense perception of truth' based on 'the powers of observation and comparison', artistic imitation may turn into 'pedantry and affectation', into an excessive attention to academic skills and technical execution that only artists can appreciate. ${ }^{14}$ It is this kind of 'excess' that Hazlitt finds in the paintings of Turner. ${ }^{15}$ In a passage often quoted in the literature on the painter:

We here allude particularly to Turner, the ablest landscape painter now living, whose pictures are, however, too much abstractions of aerial perspective, and representations not so properly of the objects of nature as of the medium through which they are seen. They are the triumph of the knowledge of the artist, and of the power of the pencil over the barrenness of the subject. They are pictures of the elements of air, earth, and water. The artist delights to go back to the first chaos of the world, or to that state of things when the waters were separated from the dry land, and light from darkness, but as yet no living thing nor tree bearing fruit was seen upon the face of the earth. All is 'without form and void'. Some one said of his landscapes that they were pictures of nothing, and very like. ${ }^{16}$

$$
\begin{aligned}
& \text { Ibid., pp. 11-12. } \\
& \text { Ibid., pp. 12-13. } \\
& \text { Ibid., p. 13. } \\
& \text { Ibid., p. 15. } \\
& \text { Ibid., pp. 16, } 18 . \\
& \text { Ibid., p. 19. } \\
& \text { Ibid., pp. 19-20. }
\end{aligned}
$$


'Pictures of nothing.' This is the title that-according to Pierre Wat in his book Turner, menteur magnifique - the art historian Lawrence Gowing wanted to give to the exhibition of Turner's paintings that he organized in 1966 at the Museum of Modern Art in New York. ${ }^{17}$ The title that was finally chosen was Turner: Imagination and Reality, but the initial idea of a painter of nothingness was preserved. ${ }^{18}$ Focusing on the (often unfinished) paintings and watercolours produced during the last two decades of his life, Gowing's exhibition promoted the vision of a Turner who, with his unique 'absorption in the intrinsic character of paint', could be considered to be a precursor of modernist abstraction. According to Gowing, in Turner's paintings 'no single touch of paint corresponded to any specific object', producing as a result the impression of an 'endless continuum' and of a 'return to a primal flux which denies the separate identity of things' ${ }^{19}$

In 1961, just a few years before Gowing's exhibition, the art historian Robert Rosenblum formulated the idea of Turner as the precursor of modern abstract painting in an article published in Art News with the title 'The Abstract Sublime' and later developed into the 1975 book Modern Painting and the Northern Romantic Tradition: Friedrich to Rothko. ${ }^{20}$ According to Rosenblum, one could trace a direct genealogical line leading from the Romantic landscapes of Caspar David Friedrich and Joseph Mallord William Turner to the abstract expressionism of Clyfford Still, Mark Rothko, Jackson Pollock, and Barnett Newman. Linking these artists together was, according to Rosenblum, a common search for the sublime, running from the 'Romantic Sublime' of Friedrich and Turner to the 'Abstract Sublime' that could be found in paintings such as Rothko's Light Earth over Blue (1954), with its 'infinite, glowing voids'. ${ }^{21}$ The reference to the Book of Genesis that we find in Hazlitt's passage- 'The artist delights to go back to the first chaos of the world, or to that state of things when the waters were separated from the dry land, and light from darkness, but as yet no living thing nor tree bearing fruit was seen upon the face of the earth. All is without form and void'-returns in Rosenblum's text. He sees in the work of Newman, Still, Rothko, and Pollock 'a post-World-War-II myth of Genesis' animated not so much by Romantic 'pantheism' but rather by a new, modernist 'paint-theism': a belief in the possibility of conveying 'supernatural experiences [...] through the medium of paint alone'. ${ }^{22}$ 
In recent years, another phrase extracted from Hazlitt's passage has become a focus of the literature on Turner: 'pictures of the elements of air, earth, and water'. The exhibition Turner and the Elements, curated in 2011-2012 by Inés Richter-Musso and Ostrud Westheider, focused precisely on the way in which Turner represents the four classical elements of air, water, earth and fire. ${ }^{23}$ As Richter-Musso reminds us in her essay in the catalogue, Hazlitt's claim that Turner's paintings are 'pictures of the elements of air, earth, and water' probably referred to two oil paintings previously exhibited at the Royal Academy: Fall of an Avalanche in the Grisons (exhibited in 1810) and Snow Storm: Hannibal and his Army Crossing the Alps (exhibited in 1812). (Figure 6.1) Both depict scenes in which nature suddenly manifests its overwhelming, destructive force. As Richter-Musso writes, 'critics widely reproached Turner for allowing the elements of air, earth, and water to entirely subsume the historical subject matter'. In the middle of a historical phase in which modern chemistry was introducing new elements, thus putting into question the classical quaternary — around 180o, thirty chemical elements had been identified, forming the basis of the modern table of the elements-Turner chooses to focus on those natural, meteorological, and atmospheric phenomena that highlight the fusion of the four classical elements rather than their distinction. Following his programme of a renewal of landscape painting through its merging with history painting, Turner presents nature as a 'cosmic force-field', the site of a tragic struggle among elements and forces that manifests itself in a variety of phenomena characterized by a constant 'dissolution and creation of forms. ${ }^{24}$ With their mutability and fleetingness, waves, rain, smoke, mist, and clouds are signs of the powers of an 'eternally changing matter', and the 'formative processes' of evaporation and condensation, accumulation and flow reveal 'the transitory nature of the natural world'. ${ }^{25}$

From the perspective we are exploring in this essay-the intersection of screen and medium - there is yet another phrase in Hazlitt's passage from 'On Imitation' that needs to be highlighted: the phrase in which Hazlitt writes that Turner's paintings are 'too much abstractions of aerial perspective, and representations not so properly of the objects of nature as of the medium through which they are seen'. What is of particular interest in this phrase is precisely the meaning Hazlitt assigns to the term 'medium' and the implications this meaning has in relation to both the status of the canvas and the visual experience of the spectator. 


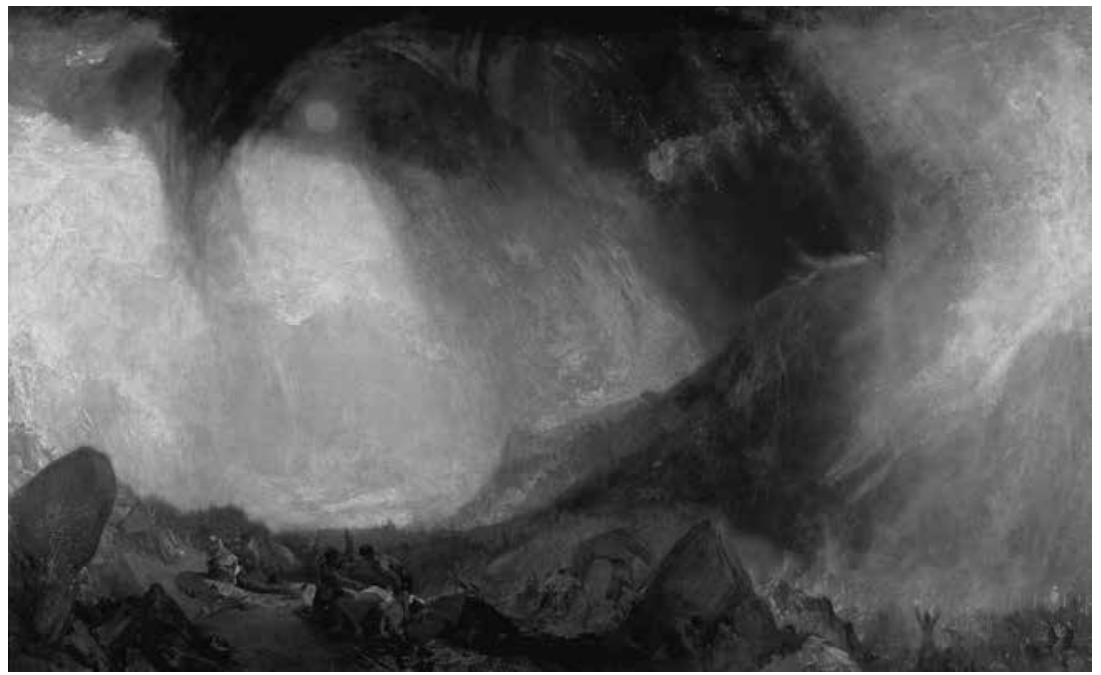

6.1: J.M.W. Turner (1775-1851), Snow Storm: Hannibal and his Army Crossing the Alps, Exhibited 1812. Oil paint on canvas, $146 \times 237,5 \mathrm{~cm}$. ๑ Tate, London 2018.

As I have tried to show elsewhere-in an essay dedicated to the meanings of the German term Medium and on the idea of a 'medium of perception' [Medium der Wahrnehmung] in the writings of Walter Benjamin-the way in which the term 'medium' is used by Hazlitt in this passage can be located within one of the multiple genealogical lines that characterize the history of the very concept of 'medium'. ${ }^{26}$ Along this line, the medium is conceived neither as an intermediary between the world of the living and the world of the dead (as in the occult, spirit tradition) nor as a set of supports and techniques defining the specificity of some kind of artistic representation, such as painting and sculpture; neither as an 'extension of man', as in Marshall McLuhan's famous definition in Understanding Media (1964), nor as a series of techniques and operations capable of storing, processing, and transmitting signals and information, as in Friedrich Kittler's notion of Medien. Even though these different meanings are often historically intertwined with one another, the way the term 'medium' is used in Hazlitt's passage is firmly rooted in a tradition that interprets as 'medium' those atmospheric substances (such as air, ether, clouds, vapour, smoke) that, taken together, constitute the environment, milieu, or Umwelt in which sensory experience unfolds. Authors such as Stefan Hoffmann and Dieter Mersch have rightly qualified such understanding of the concept 
of medium as 'aisthetic' [aisthetisch], since it is primarily correlated to a theory of perception (aisthesis) and of its spatial and material conditions of possibility. ${ }^{27}$

Considered in this perspective, Hazlitt's reference to 'aerial perspective' just before stating that Turner's paintings are 'representations not so properly of the objects of nature as of the medium through which they are seen' is directly related not only to Leonardo da Vinci's famous statements in A Treatise on Painting on the way in which the vision of objects at a distance is conditioned by the air that 'interposes between' them and the eye but also to the longue durée of a tradition that interprets the idea of medium in environmental and atmospheric terms. ${ }^{28}$ The 'medium through which' objects of nature are seen is not, here, the 'medium of paint', as in the modernist readings of Turner suggested by Gowing and Rosenblum. It is rather an atmospheric medium whose representation turns the canvas itself into an atmospheric screen. A brief detour into this idea of an atmospheric medium will help us further substantiate this idea.

\section{Clouds, ether, and the 'medium of perception'}

In his 1942 essay 'Milieu and Ambiance: An Essay in Historical Semantics', the literature historian, philologist, and critic Leo Spitzer gives a fundamental contribution to the reconstruction of what Hoffmann and Mersch present as an 'aisthetic' understanding of the medium. ${ }^{29} \mathrm{He}$ underlines the fact that 'the history of the word [ambiance] cannot be separated from that of medium and milieu', which is itself linked 'to the German Umwelt, the Spanish medio, the Italian ambiente and the English environment'. ${ }^{30}$ His

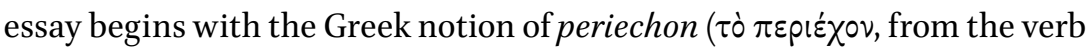
$\pi \varepsilon p l-\varepsilon \chi \varepsilon \varepsilon v)$, meaning 'that which surrounds, encompasses': a term 'used to refer to the all-embracing air, space, sky, atmosphere, climate'.$^{1}$

A further, crucial step in this tradition can be found in the notions of diaphanes and metaxy in Aristotle's treatise De Anima, which was later to

27 On the history of the concept of medium up to the beginning of the 2 oth century, with a special focus on the idea of an 'aistetic concept of medium' [aisthetischer Medienbegriff], see Hoffmann, 2002 and Hoffmann, 2006.

28 Leonardo da Vinci, p. 180.

29 Spitzer, 1942.

30 Ibid., p. 2.

31 Ibid. 
be translated in Latin with the terms diaphanum and medium. ${ }^{2}$ According to Aristotle, every form of sensory perception requires the presence of an intermediary element, the metaxy, between the perceiving body and the perceived objects. Vision, in particular, is made possible by a specific kind of metaxy called diaphanes. Although itself colourless and not visible, the diaphanes may be activated by colour, thus passing from a state of potency to a state of $a c t$, which allows it to transmit the action of colour from the object to the human sensorium, the aistheterion. 33

The way the term medium is used in medieval and modern optics, especially in the expression media diaphana, is likewise related to a theory of perception invested in the material, environmental conditions influencing the transmission of light and colour. For instance, Isaac Newton's Opticks: or a Treatise of the Reflexions, Refractions, Inflections and Colours of Light (1704, translated in Latin in 1706) analyzes the transmission of light through transparent ('pellucid') and diaphanous mediums that are both man-made and natural. Some are artificially produced and, in many ways, reminiscent of screens: prisms, lenses, crystals, and sheets of glass. Others are spatially diffused in the environment: water, oil, air, and the ether flowing between all bodies, a substance that Newton calls the 'Æthereal medium', always with a capital Æ. ${ }^{34}$

According to Spitzer, in Newton's idea of an 'Æthereal medium' we find again 'the ancient idea of a medium of perception' 35 Just as artificial entities such as lenses, prisms, and sheets of glass—all with their different degrees of transparency and opacity — are capable of influencing the transmission of light and the conditions of sensory perception, so is the ether, with its 'fluid' and 'vibrating' nature. As an 'ambient medium', the ether, according to Newton, can be 'denser', 'rarer', 'subtler', 'fluid', 'elastick', even 'quiescent', but it is never a static, passive entity. ${ }^{6}$ Rather, it is an intermediary agent, a transmitter of attractive forces, and a conveyor of light. ${ }^{37}$ The ether, in other words, is an active substance endowed with functional properties. As Spitzer writes,

32 The term metaxy was translated in Latin as medium by Michael Scotus, in his translation, around 1225, of Averroes's Commentarium Magnum in Aristotelis De Anima: a treatise in which the medium becomes the condition of possibility not only of sensation but also of thought.

33 Aristotle, De anima, B VII, 418 b, 5-6, and 419 a, 15 .

34 On the notion of 'Æthereal medium', see Newton, pp. 324, 327, 328, 343.

35 Spitzer, p. 5 .

36 Newton, pp. 195, 205, 229. The terms 'denser', 'rarer', 'subtler', 'fluid', 'elastick', and 'quiescent' appear throughout Newton's Opticks. See Newton, pp. 5, 183, 326, and 329.

37 See Spitzer, p. 35. On the ether as a medium, see Milutis, 2006; Kümmel-Schnur and Schröter, 2008. See also Henderson, 2002. 
a functional connotation (of varying intensity) is ever present [in the way in which Newton uses] the term medium; the very choice of this word in reference to the various elements reflects the point of view of a scientist conscious of the potentialities, the properties of all elements with which he has to deal; who in his experiments, in the formulation of his theories, sees any given element as a 'factor': as, in some way, an active entity, a means to an end-in the largest sense, as a means through which the efficacy of physical laws manifests itself. Thus, regardless of the multiplicity of references of which medium is capable, there is perhaps one 'meaning' throughout: an element envisaged as a factor. ${ }^{38}$

During the first decades of the nineteenth century, we find in England a whole series of examples of uses of the term 'medium' in the same material, environmental, atmospheric sense we find in Hazlitt - often by scientists with whom Turner was in direct contact. Among them, the physicist and astronomer Mary Somerville presents, in The Connexion of the Physical Sciences (1834), air, ether, and atmosphere as the 'surrounding medium' through which light and sound propagate, often using the same expression 'ethereal medium' that we find in Newton's Opticks. ${ }^{39}$ Three years before, in a letter to C.R. Leslie dated 26 September 1831, it was the painter John Constable-author of a series of Cloud Studies painted between 1821 and 1822, and accompanied by detailed meteorological 'inscriptions' - who wrote that nature is never 'divested of her chiaroscuro [...], for we never see her but through a medium'. ${ }^{40}$

References to an ambient medium that pervades the atmosphere and conditions our visual perception of the surrounding environment through its different degrees of transparency and its reflecting and refracting properties can be widely found throughout the first decades of the nineteenth century: not only within the domain of British science, literature, and painting but also within the tradition of German Romantic literature and Naturphilosophie. Before returning to Turner, a few examples from this second tradition may give us an idea of the various perceptual, epistemological, and environmental meanings that were assigned to the term Medium, directly derived from Latin, and to its German translation, Mittel.

In his Vom Erkennen und Empfinden der menschlichen Seelen (1778), Herder refers to the ether as a Medium in the sense of a fluid that pervades body 
and soul and makes all forms of sensory and cognitive experience possible. ${ }^{41}$ In the later Ideen zur Philosophie der Geschichte der Menschheit (1784-1791), it is the 'air' (Luft) that is presented as a Medium and a 'general vehicle (allgemeines Vehikel) of things' pervaded by 'effective, spiritual forces'. ${ }^{42}$ A few years later, Schelling, in Ideen zu einer Philosophie der Natur (1797), presents heat and light as pervasive 'fluids' (Fluida) that keep natural bodies together. Together with the air, they are 'the general medium (das allgemeine Medium) through which the higher forces of nature act onto dead matter': 'the medium', adds Schelling, 'in which we live, that surrounds everything, penetrates everything, and is present in everything'. 43

A metaphorical use of the term Medium can be found in Johann Wilhelm Ritter's Fragmenten aus dem Nachlasse eines jungen Physikers. Ein Taschenbuch für Freunde der Natur (1810), in which every individual entity existing in nature is presented as a prismatic, screen-like, 'light-refracting medium' (Brechungsmedium) that breaks the unity of the universal force and of the universal, divine light that pervades the created world. Life, continues Ritter, is the play of colours that is produced by such prismatic medium. ${ }^{44} \mathrm{~A}$ few years earlier, in his novel Godwi, oder das steinerne Bild der Mutter (1801), Clemens Brentano directly associates the concept of Medium with the idea of the 'romantic' (das Romantische), which in the eighth chapter is the object of a conversation among the protagonists: Godwi, Haber, and Maria, the narrator. The romantic artwork is here presented as a form of representation that does not limit itself to an imitation of the object but rather presents it through a specific, emotionally charged mediation. Maria states that 'everything that lies as an intermediary (als Mittler) between our eye and a distant object to be seen, everything that brings the distant object closer to us, and at the same time confers to it something of itself, is romantic'. Godwi adds to this the idea that the 'romantic' may be better understood if we compare it with the experience of seeing through a coloured, telescopic lens: 'the romantic is like a telescope (ein Perspectiv) or, more precisely, the colour of the glass and the determination of the object through the shape of the glass. 45

A material, environmental idea of medium - formulated through the concepts of Trübe (the 'opaque', 'cloudy', or 'turbid') and Mittel, often 
associated in the expression 'das trübe Mittel' ('the opaque medium')— plays a very important role in Goethe's Theory of Colours (Farbenlehre, 1810) and in his later writings on clouds and other atmospheric phenomena. In the 'Didactic Part' of his radically anti-Newtonian treatise, Goethe presents 'physical colours' (distinguished from 'physiological' and 'chemical' ones) as phenomena that appear within and thanks to some kind of material, colourless, and opaque medium. ${ }^{46}$ Colours, writes Goethe, are 'actions and passions of the light' (Taten und Leiden des Lichts); they are constantly transforming 'half lights' or 'half shadows' (Halblichter or Halbschatten) that manifest themselves across an intermediary region spanning between the polar opposites of light and darkness, or 'light and non-light' (Licht und Nichtlicht). ${ }^{47}$ In a short text entitled 'Das Trübe', this intermediary realm is presented as having a crucial epistemological and ontological significance, since it is in it, according to Goethe, that one finds the first manifestation of some kind of space-filling materiality, the 'first layer of corporeality' (die erste Lamelle der Körperlichkeit) ${ }^{48}$.

In his 1840 English translation of Goethe's treatise, Charles Lock Eastlake translates the expression 'trübes Mittel' with the English 'semi-transparent medium': a medium that can change in density, becoming thicker or thinner and 'more transparent'. ${ }^{49}$ As is well known, Turner, who owned a copy of Eastlake's translation and made several annotations in it, mentions Goethe explicitly in a painting entitled Light and Colour (Goethe's Theory) - the Morning after the Deluge - Moses Writing the Book of Genesis (exhibited 1843). (Figure 6.2) The painting is part of a sort of diptych with Shade and Darkness - the Evening of the Deluge (exhibited 1843)..$^{\circ}$

Although the extent of the actual influence of Goethe's Farbenlehre on Turner has been and continues to be the object of contrasting views among art historians, we may still notice how, in the painting Light and Colour (Goethe's Theory), the turbulent, circular vortex of atmospheric elements that we find often in Turner's paintings here takes on a series of yellow-red hues..$^{1}$ This particular colour palate may bear a reference to the $\S 150$ in Goethe's Farbenlehre, in Eastlake's translation:

48 Goethe, 1962, pp. 227-29. On the concepts of 'Trübe' and 'trübes Mittel' in Goethe's writings on colours and clouds, see Vogl, 2005.

49 Goethe, $1840, \S 151$, p.62.

50 See Gage, 1984.

$5^{1}$

On these two paintings and their contrasting interpretations, see Finley, 1997. 


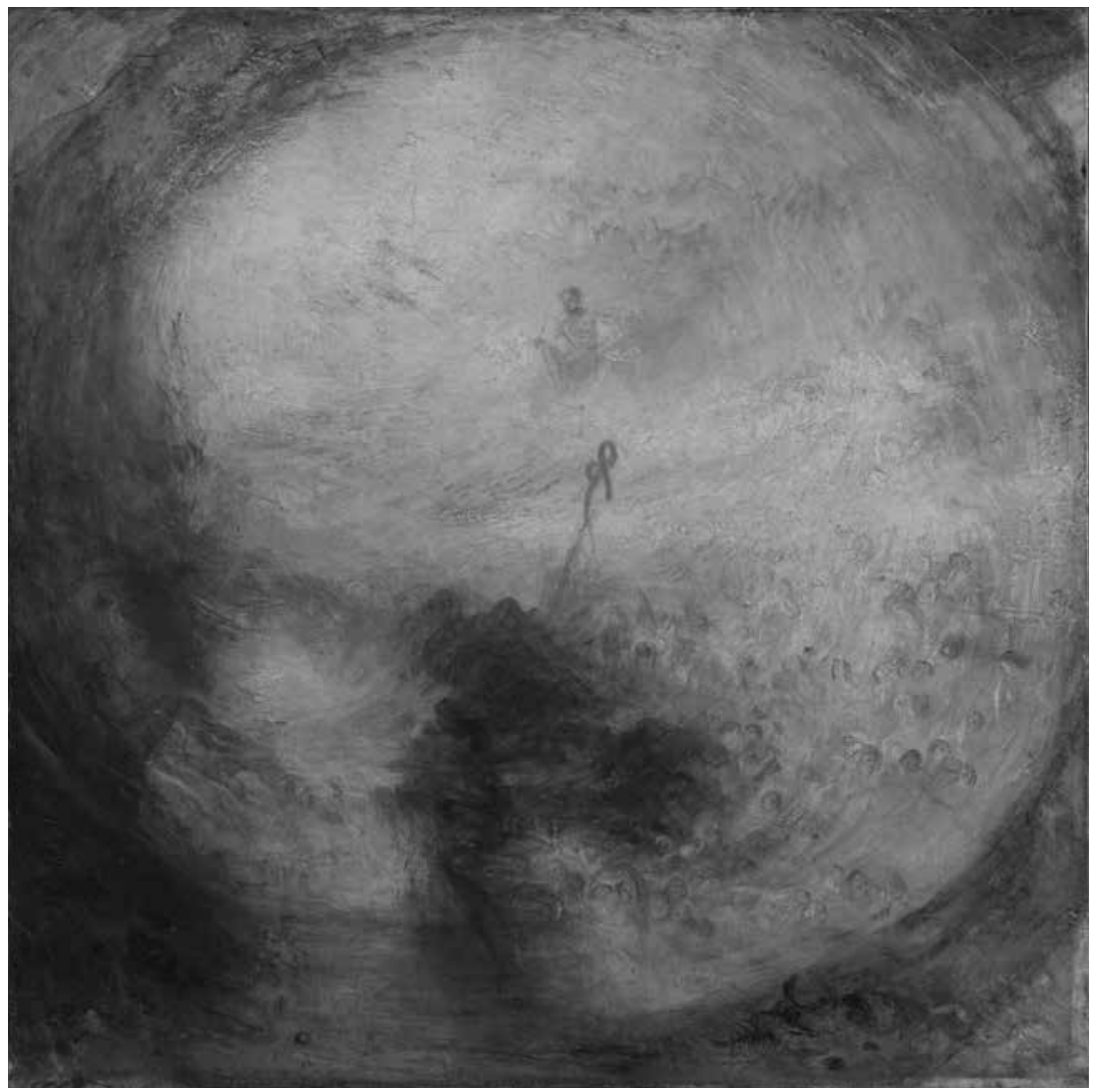

6.2: J.M.W. Turner (1775-1851), Light and Colour (Goethe's Theory) - the Morning after the Deluge - Moses Writing the Book of Genesis, Exhibited 1843. Oil paint on canvas, 78.7 X 78.7 $\mathrm{cm}$. $\odot$ Tate, London 2018.

The Highest degree of light, such as that of the sun, of phosphorous burning in oxygen, is dazzling and colourless: so the light of the fixed stars is for the most part colourless. This light, however, seen through a medium but very slightly thickened (durch ein auch nur wenig trübes Mittel gesehen), appears to us yellow. If the density of such a medium be increased (Nimmt die Trübe eines solchen Mittels zu), or if its volume become greater, we shall see the light gradually assume a yellow-red hue, which at last deepens to a ruby-colour. ${ }^{2}$ 
In the years following the publication of Farbenlehre, Goethe's interest in the 'trübes Mittel' developed into a wider interest for clouds and other atmospheric, meteorological phenomena. ${ }^{53}$ After discovering Luke Howard's Essay on Modifications of Clouds (first published in 1803, translated into German in 1815) - a text in which we find an occurrence of the term medium in the material, environmental sense we are analyzing here-Goethe dedicated a number of studies and poems to the figure of Howard and to the study of clouds: 54 for example, the poems 'Atmosphäre' and 'Howards Ehrengedächtnis', this last one divided in four parts entitled 'Stratus', 'Cumulus', 'Zirrus', and 'Nimbus', following Howard's cloud classification. ${ }^{55}$ Howard was for Goethe the one who, for the first time, had been capable of 'distinguishing between clouds', establishing divisions into what seemed to be indivisible, fixating and defining what seemed to be utterly ephemeral and indefinable. ${ }^{5}$ As we read in a letter to Carl Friedrich Zelter dated 24July 1823 , Goethe's interest in atmospheric phenomena and their metamorphic fleetingness - clouds were for him the quintessential realm of 'the transitory' (das Übergängliche $)^{57}$ - had a strong epistemological dimension, which linked it to the other areas of Goethe's natural studies, beginning with geology, that realm of stones and solid grounds that seemed to lie at the opposite of the vaporous instability of clouds:

Just as I have engaged in the study of the earth (Erdkunde) perhaps longer than I should have, I begin now to interest myself in the atmospheric realm (den atmosphärischen Reichen); and were it just to experience how one thinks and can think (wie man denkt und denken kann), that would already be an advancement (ein Vorgewinn). ${ }^{8}$

The idea that the study of clouds has a quintessential epistemological value lies at the centre, as we will now see, of John Ruskin's writings on Turner, which appear across the different volumes of his Modern Painters (1843). And it is here that the idea of a painting explicitly conceived to be 'in the service of clouds' is strictly connected to an understanding of the spectator's experience as a form of seeing through, a capacity of penetrating through

53 On Goethe's writings on clouds and other atmospheric and meteorological phenomena, see Badt, 196o; Vogl, 2005; Beyer, 2004.

54 Howard, 1865, p. 28.

55 Both poems are quoted in Badt, pp. 19-20.

56 Ibid.

57 Goethe, 1989, p. 244. Quoted in Vogl, p. 72.

$5^{8}$ Quoted in Badt, p. 19. 
the canvas as atmospheric screen, that 'veil (...) of 'intermediate being' that constitutes the sensible environment. ${ }^{59}$

\section{'Something which has no surface and through which we can plunge farther and farther'}

Ruskin's vision of Turner is almost diametrically opposed to that of Hazlitt in the essay 'On Imitation'. If Hazlitt condemns the way in which Turner insists on the mingling and the fusion of the elements within the 'medium', leading the spectator 'back to the first chaos of the world', Ruskin finds in Turner's paintings a forceful depiction of the atmosphere, allowing the spectator to experience a heightened, perceptual, and emotional immersion in the infinity of the natural environment. In watercolours such as Long Ship's Lighthouse, Land's End (1834-35) (Figure 6.3), Ruskin sees a kind of pictorial representation that is 'not formless, but full of indications of character, wild, irregular, shattered, and indefinite, full of the energy of storm', adding that 'it is this untraceable, unconnected, yet perpetual form-this fullness of character absorbed in the universal energy — which distinguish nature and Turner from all their imitators.' ${ }^{60}$

Contrary to Hazlitt, Ruskin believed that Turner's paintings, through their very insistence on the properties of the environmental 'medium', could provide a powerful epistemological tool, establishing the foundations of 'a science of the aspects of things', a science capable of studying the 'vibrations of matter' and the various forms of diaphanous, atmospheric, and ultimately screen-like mediation that could be found in nature:

there is a science of the aspects of things, as well as of their nature; and it is as much a fact to be noted in their constitution, that they produce such and such an effect upon the eye or heart [...] as they are made up of certain atoms or vibrations of matter. Turner [...] is the master of the science of aspects. ${ }^{61}$

After formulating in his 'Remarks on the Present State of Meteorological Science' (1839) the dream of 'a vast machine [...] omnipotent over the globe, so

59 Ruskin, 1903, III, p. 318; Ibid, IV, p. 101. See also Part VII ('Of Cloud Beauty'), Chapter 1 ('The Cloud-Balancings'), ibid.

6 o Ibid., p. 404.

61 Ibid., p. 387 . 


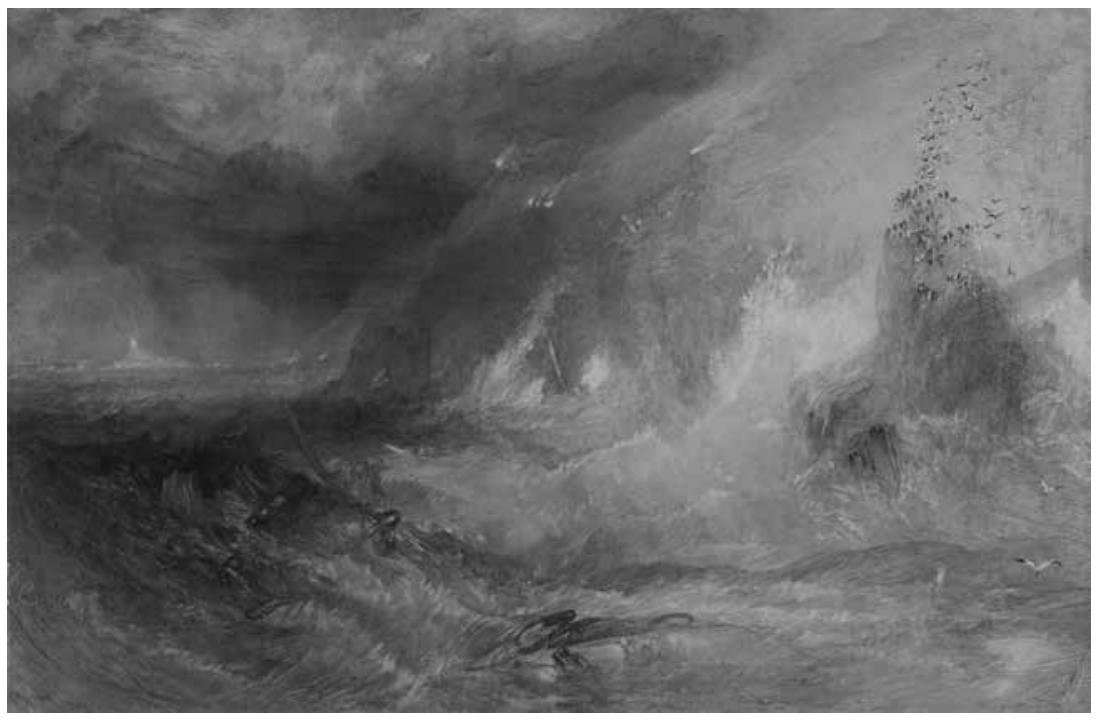

6.3: J.M.W. Turner (1775-1851), Long Ship's Lighthouse, Land's End, C.1834-1835. Watercolor and gouache, scraped by the artist $28.6 \times 44 \mathrm{~cm}$. Digital image courtesy of the Getty's Open Content Program.

that it may be able to know, at any given instant, the state of the atmosphere at every point of its surface, ${ }^{62}$ in the various chapters of the first volume of Modern Painters dedicated to the 'truths' of 'tone', 'colour', 'chiaroscuro', 'space', 'skies', 'clouds', 'earth', 'water', and 'vegetation', Ruskin describes the constant transformations, the infinite nuances of the ever-changing nature that is captured by Turner's paintings: 'This is nature! The exhaustless living energy with which the universe is filled (...) how various, how transparent, how infinite in its organization! ${ }^{63}$

Clouds play, from this perspective, a crucial role. With their division into different 'regions' (the upper region of the 'cirrus', the central region of the 'stratus', and the lower region of the 'rain-cloud'), their endless transformations ('they have no sharp edges, they are all fleecy and mingling with each other'), and their various effects of screening, filtering, and layering, they are for Ruskin a primary example of that 'infinity' that characterizes natural, atmospheric phenomena. ${ }^{64}$ It is an infinity that could only be

62 Ruskin, 1839, pp. 56-59.

63 Ruskin, 1903, I, pp. 383-84.

64 Ibid., p. 359. See also ibid., p. 387: 'If we wish, without reference to beauty of composition, or any other interfering circumstances, to form a judgement of the truth of painting, perhaps 
visualized by a form of painting explicitly conceived to be 'in the service of clouds'. 65

Being 'in the service of clouds' meant for Ruskin being capable of seizing those 'wreaths', 'halos', and 'films' on which he insists in Modern Painters: those layers and folds of a natural landscape characterized by 'an infinity of gradation [...] from the highest film that glorifies the ether to the wildest vapour that darkens the dust'. ${ }^{66}$ Situated between these various layers, human existence unfolds within an intermediate realm characterized by the presence of a number of screen-like, veiling entities, of which the cloud and the leaf are the most emblematic manifestations. As we read in the fifth volume of Modern Painters, published in 1860:

We have seen that when the earth had to be prepared for the habitation of man, a veil, as it were, of intermediate being was spread between him and its darkness, in which were joined, in a subdued measure, the stability and insensibility of the earth, and the passion and perishing of mankind.

But the heavens, also, had to be prepared for this habitation.

Between their burning light - their deep vacuity, and man, as between the earth's gloom of iron substance, and man, a veil had to be spread of intermediate being; - which should appease the endurable glory to the level of human feebleness, and sign the changeless motion of the heavens with a semblance of human vicissitude.

Between the earth and man arose the leaf. Between the heaven and man came the cloud. His life being partly as the falling leaf, and partly as the flying vapour. ${ }^{67}$

In Turner's paintings, Ruskin found a form of representation capable of visualizing and penetrating these various intermediate layers, exploring 'all those passages of confusion between earth and air, when the mountain is melting into the cloud, or the horizon into the twilight'. ${ }^{68}$ As opposed to

the very first thing we should look for, whether in one thing or another-foliage, or clouds, or waves - should be the expression of infinity always and everywhere, in all parts and divisions of parts. For we may be quite sure that what is not infinite cannot be true'.

65 Ibid., p. 318. (On the question of the representation of clouds in the history of painting, and in particular on Ruskin's idea of a painting 'in the service of clouds', see Damisch, pp. 253-276.)

66 Ibid., pp. 414-415.

67 Ibid., p. 101.

68 Ibid., p. 410 
what happened in the paintings of the 'old masters', in which 'the blue sky [is] totally distinct in its nature, and far separated from the vapours which float in it', giving the impression that 'cloud is cloud, and blue is blue, and no kind of connection between them is ever hinted at', Ruskin believes that the way in which Turner represents clouds gives the spectator the impression of looking 'through' the skies rather than 'at' them. ${ }^{69}$ Turner, we read in the first volume of Modern Painters, represents the sky as 'a deep, quivering, transparent body of penetrable air', producing a kind of 'painting of the air, something in which you can see, through the parts which are near you, into those which are far off; something which has no surface and through which we can plunge farther and farther, and without stay or end, into the profundity of space'. ${ }^{70}$

Turner - who, around 1810, for his lectures in perspective, produced multiple drawings and diagrams in different techniques studying the transmission of light and colour through diaphanous media (see, for example, the Lecture Diagrams: Reflections in Two Transparent Globes, 1810) (Figure 6.4) — promoted himself this idea of a painterly style stemming from a direct, penetrating, immersive, sensorially exposed experience of nature. In a title that refers to what is very likely a fictional anecdote, he suggests that the painting Snow Storm - Steam Boat off a Harbour's Mouth making Signals in Shallow Water, and going by the Lead. The Author was in this Storm on the Night the Ariel left Harwich (exhibited in 1842) (Figure 6.5) was conceived while being tied to the mast of a ship during a violent storm at sea, in direct contact with the natural elements. In this case the natural elements are mingled with the artificial smoke produced by the steam boat: a theme - that of the fusion of natural cloud-like vapour and man-made steam produced by boats and trains - which was to be at the centre of several of Turner's paintings during the 1830 s and 1840 s, such as Rain, Steam and Speed. The Great Western Railway (exhibited in 1844). ${ }^{71}$ (Figure 6.6)

As Lawrence Gowing writes in Turner: Imagination and Reality, 'Snow Storm is a picture of being in it': a picture in which the canvas allows the spectator to experience the environmental, atmospheric medium in which

69 Ibid., p. 347.

70 Ibid., pp. 347-348.

71 For an analysis of the implications of the mingling of nature and technique in Turner's paintings (in particular in Snow Storm - Steam Boat off a Harbour's Mouth and Rain, Steam, and Speed), see Wagner, pp. 101-105. Wagner-who refers to the connection between Turner and thermodynamics discussed by Michel Serres in his 'Turner Translates Carnot' (1982, pp. 5462) - underlines the fact that Ruskin, who was generally hostile to the process of industrialization, does not emphasize this aspect in his analysis of Turner's paintings. 


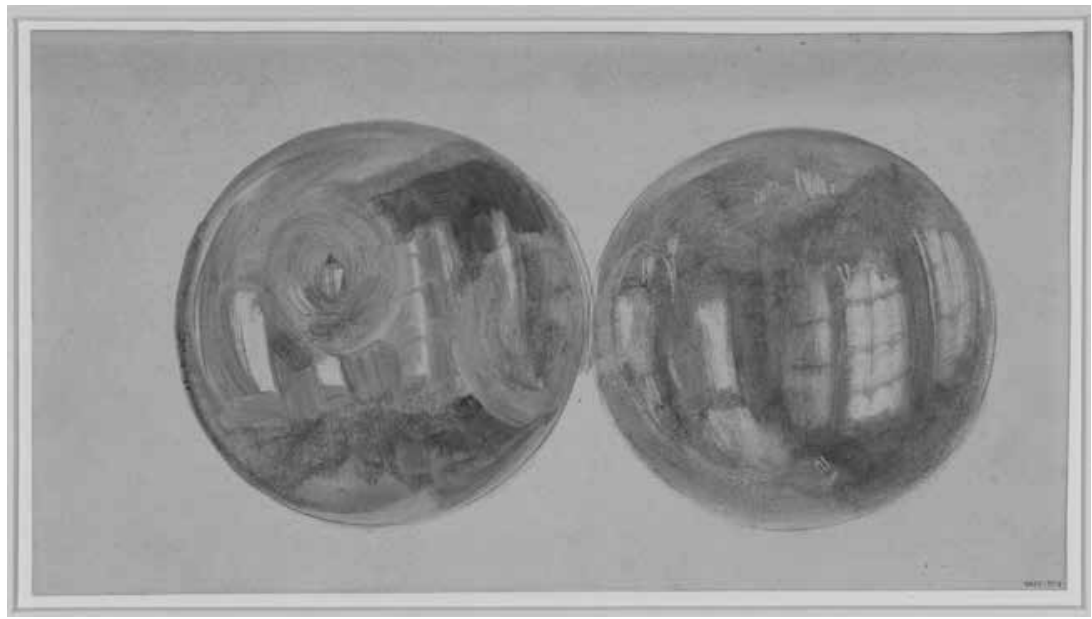

6.4: J.M.W. Turner (1775-1851), Lecture Diagrams: Reflections in Two Transparent Globes, c.1810. Pencil and oil paint on white wove paper, 21.7 x 40.4 cm. ๑ Tate, London 2018.

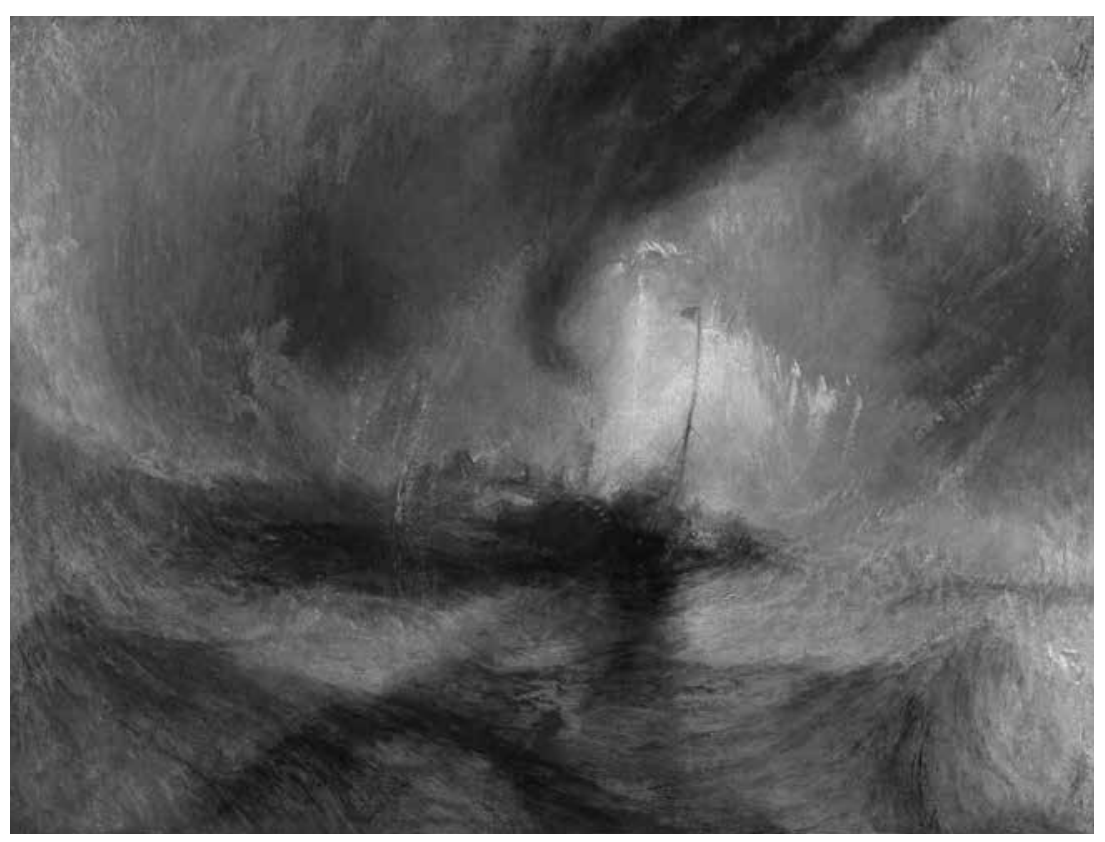

6.5: J.M.W. Turner (1775-1851), Snow Storm - Steam Boat off a Harbour's Mouth making Signals in Shallow Water, and going by the Lead. The Author was in this Storm on the Night the Aerial lift Harwich, Exhibited 1842. Oil paint on canvas, 91.4 X $121.9 \mathrm{~cm}$. ๑ Tate, London 2018. 


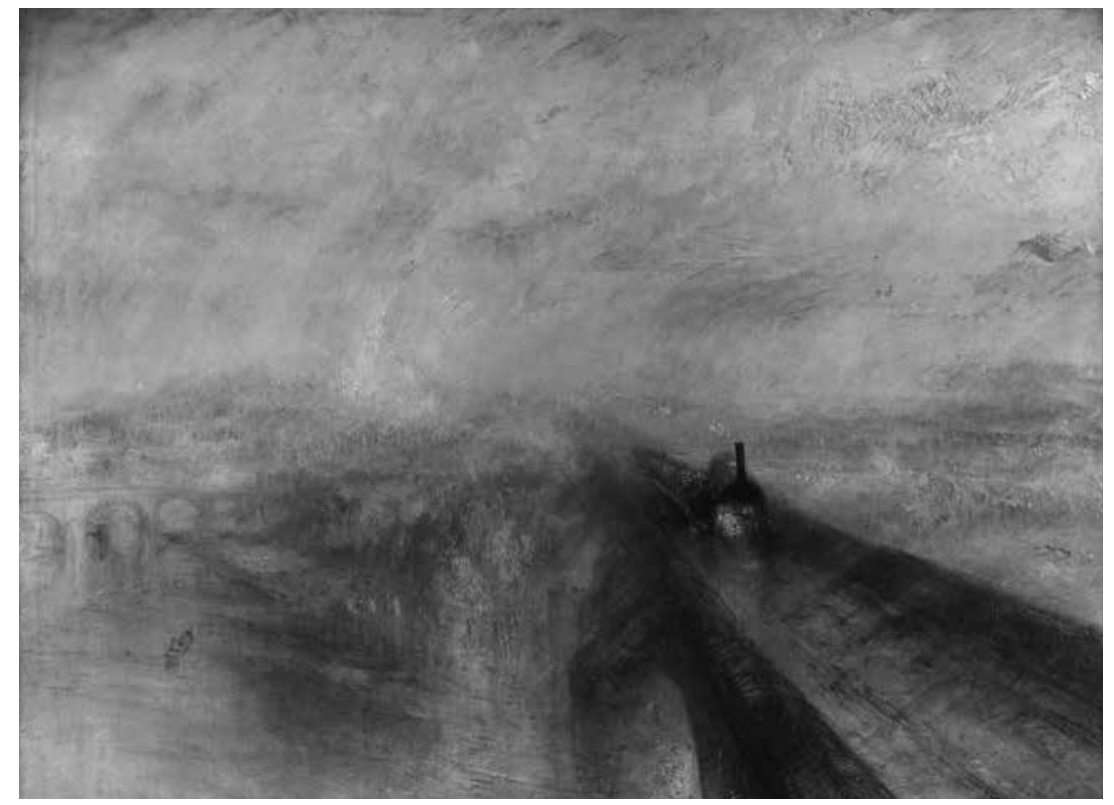

6.6: J.M.W. Turner (1775-1851), Rain, Steam and Speed. The Great Western Railway, 1844. Oil paint on canvas, $91 \times 121.8 \mathrm{~cm}$. @ National Gallery, London/Art Resource, NY.

the elements and the forces of nature intersect and transform one another. ${ }^{2}$ And this idea of being in it, of using painting in order to stage a state of immersion and even a dissolution into the atmospheric medium through the erasing of any kind of clear-cut separation between the perceiving body and the surrounding environment, is what we find in another famous painting by Turner, Regulus (1828, reworked in 1837). (Figure 6.7) The title refers to the story of a consul of the Roman Republic who served in the First Punic War (256 BC), defeating the Carthaginians in a naval battle at Cape Ecnomus near Sicily. After having invaded North Africa, Regulus was himself defeated and captured at Tunis in 255 BC. Having been sent to Rome to negotiate peace, he urged the Roman Senate to refuse the offer of the Carthaginians, who took revenge on him by torturing him to death: his eyelids were removed, and he was forced to stare into the sun until he became blind. ${ }^{73}$

72 Gowing, p. 48.

73 In his Turner, menteur magnifique, Pierre Wat draws a comparison between the historical anecdote behind the title of Turner's Regulus and a text by Heinrich von Kleist on Caspar David Friedrich's Mönch am Meer (1808-1810), in which we find another reference to a vision without eyelids: see Kleist, 1810. See also Wat, pp. 57-68. 


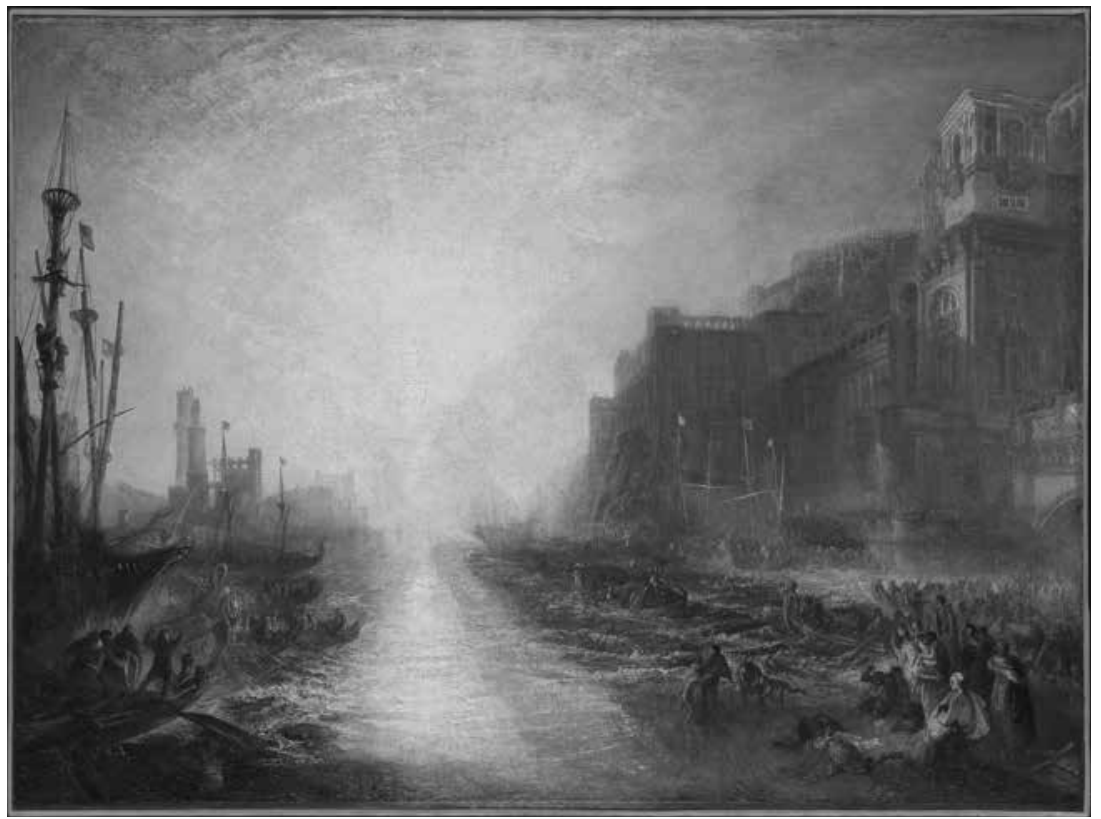

6.7: J.M.W. Turner (1775-1851), Regulus, 1828, reworked 1837. Oil paint on canvas, $89.5 \mathrm{X}$ $123.8 \mathrm{~cm}$. @ Tate, London 2018.

In his Techniques of the Observer, Jonathan Crary sees in this painting - and in later paintings such as the already mentioned Light and Colour (Goethe's Theory) - a major sign of 'the breakdown of the perceptual model of the camera obscura', with its strict separation between seer and seen. 'Seemingly out of nowhere, [Turner's] paintings of the late 1830 s and $1840 \mathrm{~s}$ signal the irrevocable loss of a fixed source of light, the dissolution of a cone of light rays, and the collapse of the distance separating an observer from the site of optical experience. ${ }^{74}$ This 'collapse', adds Crary, is most evident in paintings such as Regulus and The Angel Standing in the Sun (exhibited in 1846) (Figure 6.8), in which Turner stages a condition of full exposure to the first source of light and heat: 'in Turner all of the mediations that previously had distanced and protected an observer from the dangerous brilliance of the sun are cast off', and what we are left with is a real 'fusion of eye and $\operatorname{sun}^{175}$ that, during the early decades of the nineteenth century, can also be 


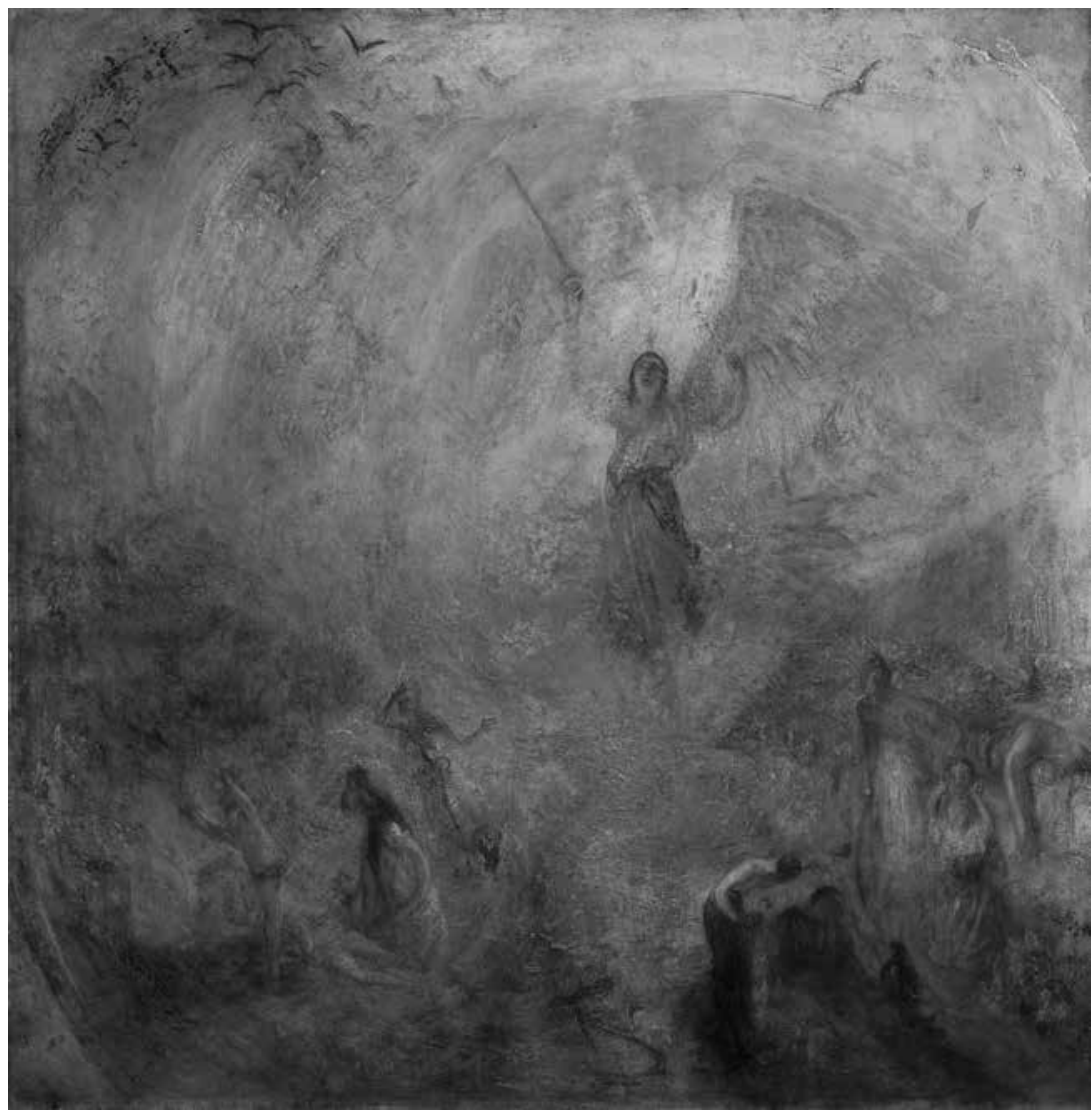

6.8: J.M.W. Turner (1775-1851), The Angel Standing in the Sun, Exhibited 1846. Oil paint on canvas, $78.5 \times 78.5 \mathrm{~cm}$. $\odot$ Tate, London 2018.

found in Goethe's understanding of the eye as 'sun-like' (sonnenhaft ${ }^{76}$ and in Gustav Fechner's view of the eye 'as a creature of the sun on earth, a creature dwelling in and nourished by the sun's rays'.77 In a text written over ten years later in an exhibition catalogue that revisits and reformulates the idea of a Turner precursor of abstraction-Aux origines de l'abstraction. 1810-1914 (2003-2004) $)^{7}$ - Crary adds that through the exposure to the 'aveuglante lumière' of Regulus, the spectator is presented with an experience 'effroyable

76 I am referring here to the famous verses mentioned by Goethe in the 'Einleitung' of the Farbenlehre: 'Wär' nicht das Auge sonnenhaft, / Wie könnten wir das Licht erblicken? / Lebt' nicht in uns des Gottes eigne Kraft, / Wie könnt' uns Göttliches entzücken?' Goethe, 2003 (1810), p. 57. 77 Fechner, pp. 39-58. Quoted in Crary, 1990, p. 142.

78 Lemoine and Rousseau, 2003. For another recent exhibition on the idea of Turner precursor of abstraction, see Rosenberg and Hollein, 2007. 
et hallucinatoire' at the same time, in which 'la distance entre le sujet et l'objet, soit entre un spectateur et le monde, s'abolit au profit d'une inscription physique du soleil dans le corps', up to the point that 'le corps du spectateur et le monde extérieur des phénomènes physiques ne forment qu'un tout indivisible'. ${ }^{79}$

Interpreted from the perspective of a study of the intersections between the environmental meanings of the terms 'screen' and 'medium', the 'fusion of eye and sun' highlighted by Crary in his reading of Turner's Regulus cannot be interpreted as a 'casting off' of all of the 'mediations' that had previously framed the observer's vision. On the contrary, what we find not only in Regulus but also in Snow Storm and in many of Turner's later paintings is an emphasis on 'mediation' that takes the form of an immersion within an atmospheric environment conceived itself as a 'medium' — an immersion within 'something which has no surface and through which we can plunge farther and farther', made possible by a canvas that has turned into an atmospheric screen.

\section{Works Cited}

Aristotle. De anima [On the Soul]. Translated by Hugh Lawson-Tancred. New York and London: Penguin Classics, 1987.

Badt, Kurt. Wolkenbilder und Wolkengedichte der Romantik. Berlin: De Gruyter, 1960. Beyer, Andreas. 'Die "Physiognomie der Atmosphäre”: Zu Goethes Versuch, den Wolken Sinn zu verleihen.' In Wolkenbilder: Die Entdeckung des Himmels, exhibition catalogue edited by Bärbel Hedinger, Inés Richter-Musso, and Ortrud Westheider, pp. 172-78. Munich: Hirmer, 2004.

Brentano, Clemens. Godwi, oder das steinerne Bild der Mutter. In Sämtliche Werke und Briefe, vol. 16. Stuttgart, Berlin, Köln, Mainz: Kohlhammer, 1978.

Casetti, Francesco. 'Notes on a Genealogy of the Excessive Screen.' In SCREENS: Genealogies of the Excessive Screen, A Mellon Sawyer Seminar at Yale. New Haven: Department of Film and Media Studies, 2017. http://dev.screens.yale.edu/sites/ default/files/files/Screens_Booklet.pdf. Accessed 12 December 2018.

Crary, Jonathan. Techniques of the Observer: On Vision and Modernity in the Nineteenth Century. Cambridge, MA: The MIT Press, 1990.

——. 'Aveuglante lumière.' In Aux origines de l'abstraction, 180o-1914. Exhibition catalogue, pp. 104-109. Paris: Édition de la Réunion des musées nationaux, 2003. Damisch, Hubert. Théorie du nuage. Pour une histoire de la peinture. Paris: Seuil, 1972. 
Elsaesser, Thomas. Film History as Media Archaeology. Amsterdam: Amsterdam University Press, 2016.

Fechner, Gustav. 'On the Comparative Anatomy of Angels.' (1825) Journal of the History of the Behavioral Sciences 5, no 1 (1969): 39-58.

Finley, Gerald. 'The Deluge Pictures: Reflections on Goethe, J.M.W. Turner and Early Nineteenth-Century Science.' Zeitschrift für Kunstgeschichte 6o. no. 4 (1997): 530-548.

Gage, John. ‘Turner's Annotated Books: Goethe's Theory of Colours.' Turner Studies 4, no. 2 (1984): 34-52.

——. Farbenlehre, 1810. Stuttgart: Verlag Freies Geistesleben, 2003.

Goethe, Johann Wolfgang. Theory of Colours. Translated by Charles L. Eastlake. London: Murray, 1840.

- 'Das Trübe.' In Naturwissenschaftliche Hefte, edited by D. Kuhn, pp. 227-229. Book 1, Volume 7 of Die Schriften zur Naturwissenschaft (Leopoldina Ausgabe), edited by D. Kuhn, R. Matthei, W. Troll and K.L. Wolf. Weimar: Verlag Hermann Böhlaus Nachfolger, 1962.

. 'Wohl zu merken.' In Schriften zur allgemeinen Naturlehre, Geologie und Mineralogie, edited by W. van Engelhardt and M. Wenzel, pp. ??. Book 1, volume 25 of n Sämtliche Werke, Briefe, Tagebücher und Gespräche (Frankfurter Ausgabe), various editors. Frankfurt am Main: Deutscher Klassiker Verlag, 1989.

Gowing, Lawrence. Turner: Imagination and Reality. New York: Museum of Modern Art, 1966.

Herder, Johann Gottfried. Vom Erkennen und Empfinden der menschlichen Seelen (1778). In Sämmtliche Werke, edited by Bernhard Suphan. Berlin: Weidmann 1892. _- Ideen zu einer Philosophie der Geschichte der Menschheit (1784-1791). In Werke in zehn Bänden, edited by Martin Bollacher and Günther Arnold,pp. ??. Frankfurt am Main: Deutscher Klassiker Verlag, 1989.

Hazlitt, William. The Round Table: A Collection of Essays on Literature, Men, and Manners. Edinburgh: Archibald Constable and Co., 1817.

Henderson, Linda. 'Vibratory Modernism: Boccioni, Kupka, and the Ether or Space.' In From Energy to Information: Representation in Science and Technology, Art, and Literature, edited by Bruce Clarke and Linda Dalrymple Henderson, pp. 126-149. Redwood City, CA: Stanford University Press, 2002.

Hoffmann, Stefan. Geschichte des Medienbegriffs. Hamburg: Meiner, 2002.

_—. 'Medienbegriff.' In Handbuch Medienwissenschaft, edited by Jens Schröter, pp. 13-20. Stuttgart, Weimar: Metzler, 2014.

Howard, Luke. Essay on the Modification of Clouds (1803). Third Edition. London: John Churchill \& Sons, 1865.

Kleist, Heinrich von. 'Empfindungen vor Friedrichs Seelandschaft.' Berliner Abendblätter, 1810. 
Kümmel-Schnur, Albert and Jens Schröter, eds. Äther. Ein Medium der Moderne. Bielefeld: Transcript, 2008.

Lemoine, Serge and Pascal Rousseau. Aux origines de l'abstraction. 180o-1914. Exhibition catalogue. Paris: Édition de la Réunion des musées nationaux, 2003. Leonardo da Vinci. A Treatise on Painting. Translated by J.F. Rigaud. London: Nichols and Son, 1835 .

Leslie, Charles Robert. Life and Letters ofJohn Constable. London: Chapman and Hall, 1896.

McLuhan, Marshall. 'Environment and Anti-Environment.' (1966) In Media Research: Technology, Art, Communication, edited by M.A. Moos, pp. 110-120. New York: G+B Arts International, 1997.

Mersch, Dieter. Medientheorie. Zur Einführung. Hamburg: Junius, 2006.

Milutis, Joe. Ether: The Nothing that Connects Everything. Minneapolis and London: University of Minnesota Press, 2006.

Moholy-Nagy, László. 'Light: A Medium of Plastic Expression.' Broom 4, no. 4 (March 1923): 283-284.

_- . Von material zu architektur (1929). Edited by by Hans M. Wingler. Berlin: Gebr. Mann, 2001.

——. 'Problems of the modern film.' Telehor (1936): 37-40.

- - The New Vision. Mineola, NY: Dover, 1975.

Newton, Isaac. Opticks, or a Treatise of the Reflections, Refractions, Inflections and Colours of Light. Fourth corrected edition. London: William Innys, 1730.

Peters, John Durham. The Marvelous Clouds. Toward a Philosophy of Elemental Media. Chicago: University of Chicago Press, 2015.

Richter-Musso, Inés. 'Fire, Water, Air and Earth: Turner as a Painter of the Elements.' In Richter-Musso and Ostrud Westheider, Turner and the Elements, 41-51.

- - and Ostrud Westheider. Turner and the Elements. Exhibition catalogue. Munich: Hirmer, 2011.

Ritter, Johann Wilhelm. Fragmente aus dem Nachlasse eines jungen Physikers. Ein Taschenbuch für Freunde der Natur (1810). Leipzig and Weimar: Müller and Kiepenheuer, 1984.

Rosenberg, Raphael and Max Hollein, eds. Turner Hugo Moreau: Entdeckung der Abstraktion. Exhibition catalogue. Munich: Hirmer, 2007.

Rosenblum, Robert. 'The Abstract Sublime.' Art News 59, no.10 (February 1961), 350-359. Available online at ArtNews.com. http://www.artnews.com/2015/03/27/ beyond-the-infinite-robert-rosenblum-on-sublime-contemporary-art-in-1961/. Accessed July 2018.

——. Modern Painting and the Northern Romantic Tradition. Boulder, CO: Westview Press, 1977. 
Ruskin, John. 'Remarks on the Present State of Meteorological Science.' In Transactions of the Meteorological Society 1 (1839): 56-59.

- - Modern Painters. The Works of John Ruskin: Library Edition. Edited by E.T. Cook and A. Wedderburn. London: George Allen, 1903.

Schelling, Friedrich Wilhelm Joseph. Ideen zu einer Philosophie der Natur (1797). Vol. 5 of Werke. Historisch-Kritische Ausgabe, edited by Hans Michael Baumgartner. Stuttgart: Frommann Holzboog, 1994.

Serres, Michel. 'Turner Translates Carnot.' (1974) Hermes: Literature, Science, Philosophy, edited by Josué Harari and David F. Bell, pp. 54-62. Baltimore \& London: The Johns Hopkins University Press, 1982.

Somaini, Antonio. 'Walter Benjamin's Media Theory: The Medium and the Apparat.' Grey Room 62 (Winter 2016): 6-41.

Sommerville, Mary. The Connexion of the Physical Sciences (1834). New York: Harper and Brothers, 1871.

Spitzer, Leo. 'Milieu and Ambiance: An Essay in Historical Semantics.' Part 1. Philosophy and Phenomenological Research 3, no.1 (September 1942): 1-42.

_- - 'Milieu and Ambiance: An Essay in Historical Semantics.' Part 2. Philosophy and Phenomenological Research 3, no. 2 (December 1942): 169-218.

Vogl, Joseph. 'Wolkenbotschaft.' In Wolken, edited by Lorenz Engell, Bernhard Siegert, and Joseph Vogl, pp. 69-78. Weimar: Bauhaus Universität Weimar, 2005. Wagner, Monika. William Turner. Munich: C.H. Beck, 2011.

Wat, Pierre. Turner: Menteur magnifique. Paris: Hazan, 2010.

Youngblood, Gene. Expanded Cinema. Introduction by R. Buckminster Fuller. New York: E.P. Dutton, 1970.

\section{About the Author}

Antonio Somaini is full professor in film, media, and visual culture theory at the Université Sorbonne Nouvelle - Paris 3. He co-directs the Laboratoire International de Recherches en Arts and is on the steering committee of the European Network for Cinema and Media Studies. He has been fellow at the Zentrum für Literatur- und Kulturforschung in Berlin (2013) and senior fellow at the International Research Institute for Cultural Technologies and Media Philosophy in Weimar (2014-15). Major publications include Cultura visuale. Immagini, sguardi, media, dispositivi [Visual Culture. Images, Gazes, Media, Dispositives] (with Andrea Pinotti, 2016) and Ejzenštejn. Il cinema, le arti, il montaggio [Eisenstein. Cinema, Art History, Montage] (2011; 2017 in English). 
